\title{
Political Education: A Preface to Justice
}

Although the virtues of the rule of law are considerable, Aristotle has revealed or suggested in discussing them at least five reasons why the rule of law needs to be complemented by the rule of men. Those reasons, to the extent that they are separable, can be summarized as follows. First, the rule of law needs human discretion to render it practical or serviceable and thereby ongoing; men will not continue the rule of law unless it can be tailored to promote the survival of particular regimes. Second, law is not fully able to determine to what it applies; human discretion needs to define the boundaries of practical affairs, or interpret the law. Law may, for example, declare its authority over military and religious matters, but human beings must decide what these matters are. ${ }^{1}$ Third, laws need human discretion to address the recalcitrance or refusal of a populace to obey them. Fourth, both the preservation and the justice of regimes call for human judgment to improve the rule of law by purging it of overly simple, barbaric, and foolish laws created by simpleminded populaces; "at Cyme, for example, there is a law concerning cases of homicide, to the effect that the accused shall be guilty of murder if the plaintiff can provide a certain number of witnesses from among his own relatives" (Pol 1268b391269a8, Met 995a3-6). Finally, equity or fairness (epieikeia), the best sort of justice, calls for human discretion since law can issue judg-

1 The Athenians undertook this task when they reinscribed their legal code in 403/2 в.C.; see Douglas M. MacDowell, The Law in Classical Athens (London: Thames and Hudson, 1978), 47-48, 160-61, 194. 
ments only about categories or classes of cases. Strictly speaking, Aristotle explains in the Nicomachean Ethics, law is not defective; it is correct to uphold the universal by automatically appealing to the usual case or precedent because this is its function. But the irregularity of practical matters is such that universal judgments cannot correctly apply to all of them. Thus, human discretion must sometimes either rectify a law itself by qualifying it or suspend its operation by issuing a decree in its place. From the perspective of equity, then, the universality of law is its defect (NE 1137b13-29). ${ }^{2}$

If human beings are to compensate for the rule of law's inadequacies without overruling its proper authority - that is, if they are to help law preserve the regime-then they must be educated in the spirit of the laws- "If the laws are popular, in a popular spirit, if oligarchic, in an oligarchic spirit" (Pol 1310a12-18). The education that is important from the political point of view is apparently not an education in complete virtue but in political virtue: "All those who take thought for good order [eunomia] give careful attention to political virtue and vice" (Pol 1280b5-6).

My first aim in this chapter is to explain the attributes that together constitute political virtue according to Aristotle. I discuss the qualities that citizens in their capacity as citizens should have as well as the qualities needed by rulers in particular. In the best regime, civic virtue and the ruling virtues coincide in all citizens; ordinarily, however, those with ruling virtues are relatively few. My second aim is to explain the means Aristotle proposes for cultivating political virtue in human beings, to make them good citizens and good rulers. Finally, I consider the discovery of those means, or the political role of philosophical virtue, and thus show that complete virtue is in fact more politically important than political virtue insofar as it is in a sense the source of the latter.

\section{Political Virtue: Virtue Redefined}

As if in response to the question, what is political virtue? Aristotle writes: "If it was correctly said in the Ethics that the happy life is

2 Like Kant, Aristotle is saying that not law but practical affairs disappoint; unlike Kant, he is nonetheless persuaded of the ability of human discretion to discover an approximately reasonable, or a kind of reasonable, course of action in the irregular circumstances of life. 
one in accordance with virtue and unimpeded, and that virtue is a mean, then the middling sort of life is best-the mean that is capable of being attained by each sort of individual. These same defining principles must also define virtue and vice in the case of a city and a regime" (Pol 1295a35-40). If a city ought to follow that way of life that stands as a mean to it, then it follows that a citizen ought to follow that way of life that stands as a mean to the regime. Good citizens are, then, more virtuous than the regime in which they live. For example, whereas the best form of democracy is the most moderate form with respect to the extreme form, the best democrat is moderate with respect to the standards set-not by the extreme form of democracy-but by the most moderate form of democracy. The best democrats, then, even more than the best democratic laws, recognize claims in addition to freedom and equality. What enables citizens to be more moderate than the laws under which they live is civic virtue. The elements of civic virtue enable them to temper their foremost political desire (for freedom, equality, economic equality or preeminence, power or dominance).

The civic virtue exercised by the citizens in the best regime, like ordinary civic virtue, partakes of the mean. But this mean is the true mean. Civic virtue that upholds the true mean is moral virtue simply. The character and conduct of the citizens in the best regime are then 'extreme' in that they always, in public and in private, are morally virtuous.

Not all citizens in ordinary regimes partake of the civic mean and thereby surpass the laws in goodness. Indeed, some are not even as good as the laws, for private upbringing and character often influence them more than the laws: "It has happened in many places that, although the regime insofar as it is based on the laws is not a popular one, it is governed in popular fashion as a result of the [citizens'] character and upbringing [tēn agōgēn]. Similarly, it has happened elsewhere that the regime insofar as it is based on the laws tends toward the popular, but through the [citizens'] upbringing and habits tends to be oligarchically run" (Pol 1292b1217). Likewise, we can infer that some citizens surpass the standard of civic virtue for their regime. In short, because of nature and nurture, the virtue of citizens in the same regime varies; a zealot may live next door to a spoudaios. ${ }^{3}$

3 Although Aristotle makes no reference to nature here, it is possible because of his use of agogge in addition to ethos that he means by the latter the natural temperament or inclinations of individuals. 
Aristotle has suggested three reasons for regimes to cultivate in their citizens political virtue that goes beyond mere obedience to the laws. First, the laws themselves may not be good; to follow the way of life they set forth may be to live licentiously or acquisitively, for example. Second, even if the regime is the moderate form of its type, citizens can effect the better sort of eunomia, which goes beyond the observance of laws as such. Third, an education in civic virtue has more potential than the laws to remedy a bad character and upbringing and to enhance a good character and upbringing.

According to Aristotle, civic virtue comprises five main qualities: (1) self-restraint or temperance, (2) trustworthiness and a capacity to trust, (3) thoughtfulness, judgment, or prudence, (4) spiritedness, and (5) goodwill, or the capacity for concord. In educating citizens not simply in the spirit of the regime but in the spirit of the mean relative to it, a regime twice redefines virtue-moving away from the true mean, and back again toward it.

\section{Self-Restraint or Temperance}

Citizens in any regime should resist the impulse to steal, whether need or want generates that impulse (Pol 1267a2-5). Most need the help of education to check their desires (Pol 1266b29-31). Ideally, education should dissuade persons from even coveting excessive possessions or from "money-loving." As noted in Chapter 4 , one should desire wealth only in order to meet needs and to be generous to others. ${ }^{4}$

In the modern liberal view, as derived especially from Hobbes, the concept of good or goodness collapses into that of want or interest such that "the sole measure of good that remains is the wants of an individual or some combination of the wants of individuals revealed by the choices they make. The good has no existence outside the will." 5 According to Aristotle, the will is only one part and the least noble part of the soul. It becomes more noble not as it recedes but as it accords with the rational, more noble, part of the soul (Pol 1333a16-29; NE 1098a7-8, 1102b28-31). Thus, educa-

\footnotetext{
4 Aristotle makes the following distinctions. Those without self-restraint, or the self-indulgent (akolastoi), do not resist their desires that are inconsistent with virtue (for example, they want to loaf instead of write their term paper and so loaf); the self-restrained or continent (engkratoi) resist such desires (they want to loaf but write their term paper); the temperate (sōphronēs) have only desires consistent with virtue (they want to write their term paper instead of loaf) (NE 1102b26-28, 1119a1-18).

5 Roberto Mangabeira Unger, Knowledge and Politics (New York: Free Press, 1984), $67-68$
} 
tion should not suppress but ennoble the passions of citizens. This benefits not only the regime but the individual, in saving him from the futility of trying to satisfy his untempered passions and from the resulting lost opportunities for a complete life.

\section{Trust and Trustworthiness}

Citizens should be trustworthy so that trust may be forthcoming among them. Trust should predominate for many reasons, but mainly because a regime cannot last unless its citizens trust each other enough to let others rule. Since it is just to distribute offices according to merit, citizens need to trust each other's judgment about what constitutes merit or virtue (which is why the rich and the poor do not let each other rule) (Pol 1326b14-18, 1297a4-6). If such trust does not prevail, then offices will change hands only by usurpation. Similarly, unless trust prevails, the ruled may not abide the decisions of the rulers; offices will lose their power to command.

The prevalence of trust also safeguards a regime against the rise of a tyrant or demagogue; when citizens are divided, one who wants to rule only for personal advantage can easily rise to power. Citizens heed such a person because, though not serving their interests, he does not serve the opposition's interests either. In contrast, when citizens are united or trust one another, they together distrust one who appears unworthy of ruling. In other words, the trusting and trustworthy - that is, the respectable-do not submit to the rule of a tyrant out of distrust of the alternative, rule by their fellow citizens. Consequently, "[tyrants] make war on the respectable as being harmful to their rule"; a shrewd tyrant knows that "a tyranny will not be overthrown before some persons are able to trust each other" (Pol 1314a17-23).

Finally, citizens should be trustworthy enough to keep agreements and trust others enough to keep them, for a city cannot exist without agreements of all kinds. To live together citizens must agree at least not to violate each other's persons or property and to exchange goods (Pol 1280b29-32). "For the most part [the wealthy] are more trustworthy regarding agreements" (Pol 1283a32-33)perhaps because the wealthy, being less needy than others, do not attempt to cheat or swindle to procure what is not theirs legally or by agreement. At any rate, the opportunity for gain, being an opportunity to satisfy needs, especially invites persons to be untrustworthy. 
For trust to prevail, "the citizens must necessarily be familiar with [gnōrizein] one another's qualities" (Pol 1326b16-17). Human beings trust one another only if they deem the other's character sound, and they cannot render such a judgment without being familiar with the other. Perhaps Aristotle is saying that citizens need, not to know each other personally, ${ }^{6}$ but to recognize in each other desirable, trust-eliciting qualities. In any case, he observes that a tyrant, in trying to undermine or preempt trust among his subjects, will do everything possible to render or to keep them unfamiliar with each other-such as prohibit academies, intellectual gatherings, and ath-

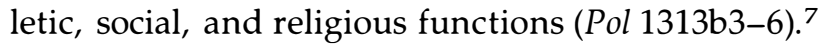

\section{Thoughtfulness, Judgment, or Prudence}

A third salient element of political virtue is thoughtfulness, judgment, or prudence. According to Aristotle, the Greeks, being as a race more endowed with thought (dianoetikon) than peoples of cold countries, govern themselves in a manner much superior to the way northerners govern themselves and show, also in contrast to northerners, the ability to rule others (Pol 1327b24-33). Thought (dianoia) appears then to be a necessary condition of prudence (phronēsis), the capacity to rule and to be ruled (Pol 1277a14-16, 2527, 1333a11-13). If thought is presupposed by, but is not the same thing as, prudence, then perhaps what Aristotle means by it is thoughtfulness - that quality that compels one to think, or one might say calculate, before doing or acting. It would thus complement both technical skill (technē) and prudence (phronessis), the two lower-order intellectual faculties (NE 1139a6-12, 1140b35-1141a1). It is better, for example, to think to shut off the water before fixing the plumbing and to think before issuing a decree. Having done so does not mean, however, that one knows how to fix the pipes (has techne) ), or knows what action is good for the country (has phro$n \bar{e} s i s)$. Without thoughtfulness, then, people are less inclined to heed others or to be guided to virtue (Pol 1327b36-38) - preferring to act rather than to listen or think-and less inclined to make sound judgments or rule well-preferring quick to deliberate decisions.

6 Ernest Barker claims that Aristotle means the opposite; see The Politics of Aristotle (Oxford: Clarendon, 1948), 292 n. 3.

7 Carnes Lord's explanation of scholai ("leisured discussions") and syllogoi scholastikoi ("meetings connected with leisure"); see Aristotle: The Politics (Chicago: University of Chicago Press, 1984), 263-64 n. 104. 
Aristotle seems to be saying that good political order requires citizens who have some degree of caution and are thus willing to consider or, as the case may be, reconsider decisions before executing them. That the Carthaginian oligarchs allow the people to challenge some of their proposals is not commendable insofar as it is a deviation toward democracy ( $\mathrm{Pol} \mathrm{1273a4-13)} \mathrm{(though} \mathrm{advisable} \mathrm{as} \mathrm{a}$ safeguard against discord); nonetheless, it evinces the oligarchs' willingness to reconsider their decisions before making them law. Without such reconsideration, there cannot be decisions that deserve to be called judgments. And, as we have learned from Aristotle, without judgments human beings cannot live together; even if an association is constituted of all those persons needed to furnish the necessities of life-such as weavers, farmers, shoemakers, and builders- "there must necessarily be someone who assigns and judges what is just [krinounta to dikaion]." Indeed, in the sense that we should consider the soul of an animal to be more important than its body, we should, to recall, consider the part of the city that judges or deliberates (whether over judicial or political matters) to be more important than even those parts that provide food, clothing, and shelter (Pol 1291a22-28).

It seems, on the one hand, that regimes cannot make their populaces thoughtful, because thoughtfulness appears to be a natural virtue that "must [already] be present [ta men huparchein]" in a city (Pol 1327b19-20, 1332a28-29). On the other hand, Aristotle indicates that thoughtfulness makes people yield easily to virtue ( $\mathrm{Pol}$ 1327b36-38). Perhaps he is saying that, insofar as legislators cannot create thoughtfulness, it is a natural endowment; but insofar as they can transform it into good judgment or deliberation and, in some persons, even prudence (the ability to carry out deliberative decisions; NE 1140b20-21, 28), it is a (supremely important) political virtue.

\section{Spiritedness}

In addition to being self-controlled, trustworthy, and thoughtful, citizens should also be spirited (enthumon). If they are not, their fate may be that of the Asians-perpetual subjection and enslavement (Pol 1327b27-29). Spiritedness protects a people against enslavement because, one might surmise, it is fierceness, or a readiness to fight. The spirited man is not by nature aggressive, but rather he is willing to be so. Perhaps Aristotle is agreeing with the Athenian 
Stranger that "every real man should be of the spirited type, but yet also as gentle as possible. For there is no way to avoid those injustices done by others that are both dangerous and difficult, or even impossible, to cure, except to fight and defend oneself victoriously, in no way easing up on punishment. This, every soul is unable to do, if it lacks a high-born spiritedness." ${ }^{8}$ But Aristotle criticizes Plato for depicting the guardians of his city-who, like dogs, attack outsiders-as too harsh. One should not be harsh even to strangers, Aristotle says. It appears, moreover, that spiritedness in his view is nothing like fierceness, for "spirit . . . is the capacity of the soul by which we feel love." Hence it is "a thing expert at ruling [archikon]" us (Pol 1327b38-1328a1, 7-8).

If, however, spiritedness is the capacity that feels or is aroused by affection (ho thumos estin ho poion to philetikon), how does it allow the Greeks to remain free and self-governing (Pol 1327b40-41, 3133)? Perhaps it makes them "keenly alive to the obligations of friendship"9 or, more broadly, protective of what is their own. Human beings feel affection for what is their own and dear ( $\mathrm{Pol}$ $1262 b 22-23)$, and when the objects of their affection are threatened spirited human beings become aroused, ready to protect what they hold to be good. ${ }^{10}$

The spirited person is, then, harsh only in reaction to those behaving unjustly (adikountas) (Pol 1328a10). Otherwise, it appears, he is gentle. Aristotle therefore agrees with Plato but emphasizes that it is not unfamiliarity per se but injustice that arouses the spirited man-who is not like the dog who attacks all strangers but the tame dog, the dog who attacks when he senses a danger or threat to his masters, those he "owns."11 Like the tame dog, he is noble, not beastlike (Pol 1338b29).

In being a disposition to protect what is one's own and dearwhat is private-spiritedness is not a mere willingness to fight, an ability to be piously cruel, or even spite. It is rather a moral sensibility or posture, a loyalty to what is not simply one's own but one's own and dear or thought to be good. It is the disposition or

8 Plato, Laws, 731b.

9 Politics, trans. Barker, 296 n. 3.

10 Hence children, being, as Aristotle and Socrates observe, "full of spirit straight from birth" (Plato, Republic, 441a; Pol 1334b22-24), often cling fiercely to things that are theirs or that they believe to be theirs.

11 Plato, Republic, 375e. 
feeling that, in Aristotle's view, human beings properly have toward those things that are truly private. Being a loyalty or commitment to what is good and one's own, it is the disposition that someone may have about not only intimates and friends ( $\mathrm{Pol}$ 1328a1-2, 10-11) but also the activity of philosophy. ${ }^{12}$

Thus, spiritedness is not in Aristotle's view blind or simple patriotism. Esteem-for friendships, family, a way of life-moves human beings to protect themselves. Spiritedness thus springs from or is attached to judgment. ${ }^{13}$

That spiritedness is aroused by threats to what people esteem means that it manifests itself variously. Friends and intimates "choke with rage" (with good reason) when what they have with one another is slighted (Pol 1328a5, 13-14); citizens who esteem their way of life go to war if attacked; and one who esteems the contemplative life, like Socrates, protests if it is threatened. Although such individuals may not themselves be victorious, their spiritedness shows itself until their end, for spirit is an "indomitable thing [aēttēton]" (1328a7).

\section{Goodwill}

If spiritedness is a commitment to what is held dear, then it is inseparable from affection ( $\mathrm{Pol} 1327 \mathrm{~b} 40-41$ ); and since spiritedness motivates people to defend their regime, it is not surprising that affection or friendship (philia) is "the greatest of good things for cities" (Pol 1262b7-8). But friendship is also a great good for cities in that it seems to hold them together (NE 1155a22-23) by safeguarding them against civic conflict ( $\mathrm{Pol} 1262 \mathrm{~b} 8-9)$, encouraging voluntary sharing of possessions (Pol 1263a38-39), and rendering them more than alliances (Pol 1261a24-25, 1280a31-35, b29-31). For these reasons, Aristotle appears to be against diluting friendship between citizens (Pol 1262b15-16).

Still, as people become closer and their claims of friendship increase, their spiritedness becomes more easily aroused (Pol 1328a12)-suggesting that where friendship exists between citizens the potential for civic conflict is great. Moreover, much of Book II is devoted to the point that too much unity destroys a city (e.g., Pol

12 Ibid., 376c.

13 It is perhaps because spiritedness is a kind of moral virtue that farmers should not be of a spirited stock (Pol 1330a27); that is, those who are spirited should be not farmers but citizens. 
1261a16-21, II.2-6). So Aristotle's statement against dilution of friendship in cities is in fact a statement against an excess of affection, a condition certain to bring about such dilution (Pol 1262b1016).

The friendship Aristotle deems the greatest good for cities is then a particular species of friendship-namely, concord (homonoia) (NE 1155a24-25). Concord lies between enmity on the one hand and (other types of) friendship on the other (1155a25-26, VIII.3). It is unlike enmity because goodwill (eunoia) characterizes it; but it is unlike the other types of friendship (for utility, pleasure, and virtue) because the goodwill is not reciprocal (1155b33-34). Goodwill between citizens is not reciprocal because it is not the (mutual) appreciation of specific qualities (sucht as beauty, wealth, or goodness) by specific persons but is ra'..er appreciation of a general attribute of all (or most) persons. As Aristotle explains, "many a person has goodwill to those whom he has not seen but assumes to be decent or useful, and one of these might have the same goodwill toward him. These people, then, apparently bear goodwill to each other, but how could we call them friends when they are not aware of each other's regard?" (1155b34-1156a3, 1157b18-19).

Concord appears, then, to be conducive to or expressed in lawabidingness, in that abiding the law-not killing, robbing, or otherwise harming others-is an expression of goodwill, a recognition of the decency or at least usefulness of others (insofar as living with others in peace rather than enmity facilitates living). That concord may stem from a recognition of simply the usefulness of other citizens indicates that it is close on the spectrum of friendship to utilitarian friendship. But to call it utilitarian friendship would be in Aristotle's view to overstate what it is, since it does not satisfy specific needs or wants. Not rooted in particularity and thus proximity (NE 1157b10-13, 19), concord is a diffuse, watery kind of association.

Although Aristotle does not think that citizens can reciprocate goodwill, he does think that they should reciprocate equality ( $\mathrm{Pol}$ 1261a30-31), that is, equality of treatment: "Men seek to return either evil for evil_-if they cannot, they feel they are in the position of slaves-or good for good-if they cannot, no exchange takes place." In short, "proportionate reciprocity holds together a city" (NE 1132b31-1133a2). Aristotle thereby suggests the conclusion 
that concord, insofar as it is manifested as law-abidingness or respect for the law, makes possible the dispensation of rewards and punishment, or justice. Understandably then, legislators are more concerned about (political) friendship than about justice ( $N E$ 1155a23-24).

\section{The Ruler's Virtues: Prudence, Temperance, and Justice}

Rulers should have all the virtues of a good citizen, but they should have especially prudence (not simply thoughtfulness or judgment), temperance (not simply self-restraint), and justice (not simply goodwill).

Rule is not, properly speaking, rule in Aristotle's view unless those ruling possess prudence. As explained in Chapter 5, a regime may have to establish other qualifications for office, but it should make prudence a qualification for as many offices as possible and especially for the most important ones.

Prudence is the defining virtue of a ruler according to Aristotle (Pol 1277a14-16, 23, b25-26) for two reasons. First, it is the faculty that translates, by good deliberation, judgments into actions ( $N E$ 1143a7-10, 1140b3-7, 15-16, 1141b12-14, 21), thus enabling the ruler to issue (good) commands (epitaktike) (NE 1143a8). ${ }^{14}$ In presupposing judgment, prudence distinguishes the ruler from the clever incontinent or evil man, who can also obtain his desired end (NE 1142b18-20). ${ }^{15}$ In presupposing judgment and effecting it, prudence distinguishes the ruler from the man of understanding (sunesis), who can neither judge by himself ${ }^{16}$ nor actualize a judgment (NE 1143a13-15). Finally, in actualizing judgment, prudence distinguishes the ruler from the man of judgment (gnōmen), who is capable of rendering judgments alone and thereby of holding true opinion (doxa alēthess) but cannot apparently effect judgments ( $N E$ 1143a8, Pol 1277b28-29). In distinguishing between the man of un-

\footnotetext{
14 See also Eric Voegelin, "What Is Right by Nature?" in Anamnesis, trans. and ed. Gerhart Niemeyer (Notre Dame: University of Notre Dame Press, 1978), 67, 69-70 and, acknowledging Voegelin, Ronald Beiner, Political Judgment (Chicago: University of Chicago Press, 1983), 74-75.

15 Both the prudent and the clever man can, by deliberating or calculating correctly (orthōs), figure out the means to achieve a certain end; but only the prudent man deliberates well (eu) - that is, nobly (kalōs) ( $N E$ 1143a14-15)-because the means he arrives at effect a good end (embodied in judgment) (NE 1142b18-22, 2733, 1143a26, 28-35).

16 At NE 1143a9-10, Aristotle states that "understanding judges," but then he explains two lines later that it judges "what someone else says" (1143a13-15).
} 
derstanding and the man of judgment, Aristotle seems to be drawing a distinction between those members of a regime who are only able to be unquestioningly law-abiding and those who are able to hold and voice their own, perhaps critical, judgments of the regime. ${ }^{17}$ Aristotle suggests that yet another sort of citizen might exist-those who have the capacity to be prudent but prefer to engage in theoretical speculation, speaking out against the regime only if and when it threatens their preferred activity. ${ }^{18}$

Prudence is also the defining virtue of a ruler, according to Aristotle, because it effects what is good for the whole. It is the ability "to deliberate nobly about . . . what conduces to the good life in general" (NE 1140a25-28, 1141b12-14). Rulers do not deliberate about what the good life is, for it is impossible to deliberate about what does not vary (1140a31-32, 1141b10-11); rather, they deliberate about the means to obtain it, which do vary. But, in order to deliberate about these, they must have in view the end (1141b1112). Not being able to arrive at what is universally good on their own (1141a29, b14-15, 1142a25-26), they seek to learn it, as has been explained, from law (1141b24-26) which embodies to varying degrees the insights of the wise. In deciding what to command or decree, rulers consider the law and the particulars at hand. ${ }^{19}$ If the

17 The likelihood that persons of judgment would criticize their regime is presumably a function of the number and authority of prudent office-holders. That any regime can have both critical and uncritical members is possible and likely because understanding and judgment are natural endowments (NE 1143b6-7). Voegelin seems to collapse judgment (gnōmé), which Aristotle discusses in NE VI.11, and understanding (sunesis), which Aristotle discusses in NE VI.10, when he states that "synesis is the virtue of right judgment and understanding (kritike)" and explains that the sunetos (not also the man of gnōme) is different from the phronimos because he cannot act effectively. Or, he subsumes gnōmē under phronēsis. In any case, he does not address gnōmē in his discussion of phronēsis ("What Is Right by Nature?" 69-70). Although Aristotle does use krisis (judgment or discrimination) to describe the activity issuing in understanding (sunesis) (NE 1143a10, 14, 15, 30) and in judgment (gnōmé) $(1143 \mathrm{a} 20,23,30)$ and says that both sunesis and gnommé concern particulars (1143a28-29), the fact that he uses two different words cannot be ignored; the strongest case for accounting for it seems to be the difference between following another's reasoning and reasoning on one's own (the latter easily subsumes the former). This interpretation is supported further by what seem to be distinctions between understanding, judgment, and prudence: "There being two parts of the soul that can follow a course of reasoning, [prudence] must be the virtue of one of the two, namely, of that part which forms opinions. . . . But yet [prudence] is not only a reasoned state" $(1140 \mathrm{~b} 25-26,28)$.

18 In the best regime, citizens have actual prudence when ruling and latent prudence when being ruled ( $\mathrm{Pol} 1277 \mathrm{a} 13-14,20-23$ ).

19 My point is contrary to Ronald Beiner's suggestion that the prudent man does not consider codified principles (Political Judgment, 73). 
law does not stipulate what would be fair, they rectify this deficiency by prescribing what they deem fair rather than what is legally just (1137b19-27, 1140b4-6, 1143a31-33). Accordingly, prudence shapes legislative wisdom and politics (1141b24-28).

In effecting what is good for the whole, the ruler displays justice, for justice is by definition the exercise of virtue in relation to others (NE 1129b25-27, 32-1130a1; Pol 1277b16-18). Good citizens too are just, but not fully, since they lack the capacity, not to ascertain what is good for the whole, but to effect it. ${ }^{20}$ Having the justice characteristic of being ruled ( $\mathrm{Pol} 1277 \mathrm{~b} 18-21)$, good citizens apparently attend largely to their own affairs.

Prudence also presupposes temperance. The word sōphrosune $\bar{e}$ (temperance) derives from sozzein (to preserve, maintain) and phro$n \bar{e}$ sis (prudence); we imply by the word sōphrosunē, Aristotle says, that "it preserves one's prudence [sōzousan tēn phronēsin]" (NE 1140b11-12). Again, good citizens too are moderate, but in a way befitting being ruled ( $P o l$ 1277b18-21), which may mean that selfrestraint suffices for the ruled, at least in most regimes.

\section{The Guiding Principles of Political Education: "The Possible and The Proper"}

Having reviewed the nature of political virtue, we can now turn to the ways of cultivating it. On the one hand, Aristotle declares, "education relative to the regimes" is "the greatest of all the things" that makes regimes last (Pol 1310a12-14). On the other hand, in advising all cities to try to realize as much as possible the happy, that is, the virtuous or noble life, he indicates that the aim of education should be to make citizens as virtuous as possible ( $\mathrm{Pol}$ 1323b30-36, 40-1324a2, 12-13). ${ }^{21}$ Taken together, these two prescriptions repeat the claim that the virtue that citizens should have should constitute a mean relative to their regime. Education should form characters supportive of the regime yet should also prepare and encourage individuals to actualize their human potential. In calling for the actualization of potential, Aristotle is, one should remember, calling not only for excellence but for diversity,

20 Strictly speaking, then, politics is properly the domain of rulers not citizens.

21 See the Appendix, "The Composition of the Politics," pp. 221-26. 
since a city's existence depends on the preservation of differences not inimical to virtue (Pol 1261a24, 29-30). In short, education must make persons at once excellent citizens, excellent human beings, and excellent individuals.

It should be noticed that, in advising an educational solution to the problem of realizing the end of the city, Aristotle implicitly rejects the characteristically modern judgment that institutional remedies to political problems are more realistic than educational ones. In Aristotle's view, institutional regulation is not to be preferred because it at least jeopardizes the actualization by human beings of both excellence and talent or individuality. It is neither realistic nor desirable to try to achieve political unification through uniformity. ${ }^{22}$

If an educational system is to preserve difference or choice and foster excellence or the making of good choices, then it should not expect the same level of performance from all. Uniformity of achievement results only if the standard of achievement is set by the capabilities of the least capable, which may be no standard because, as Socrates and Aristotle note, "there may be persons who are incapable of being educated and becoming good men" (Pol 1316a10-11). At the same time, education cannot without cost to its effectiveness ignore the limitations nature insists on imposing on individual human beings. In short, it must accommodate the inequality that is and will continue to be a feature of all regimes at all times (Pol 1316a11-14).

Since the extent to which individuals can actualize virtue (aretess energeia) ranges from not at all to completely (Pol 1328a37-40), education should adopt as guiding principles the two aims that individuals should undertake for themselves-namely, "the possible and the proper [or fitting; to te dunaton kai to prepon]" (Pol 1342b1720). Yet fourteen lines later (1342b33-34), concluding the last paragraph of the Politics, three principles- "the mean, the possible, and the proper [to te meson kai to dunaton kai to prepon]" - are recommended to guide education. Why Aristotle adds this third term to his initial list of principles, and what he means by these three terms, deserves consideration.

22 See Leo Strauss, Natural Right and History (Chicago: University of Chicago Press, 1953), 193-94, which contrasts the ancient view of institutions with the views of Hobbes and Kant; and Eric Voegelin, Plato and Aristotle, vol. 3, Order and History (Baton Rouge: Louisiana State University Press, 1957), 323. 
What Aristotle means by "the possible" as a guiding principle for education seems evident: it would be absurd to ask of human beings what nature prevents them from achieving or makes unreasonably difficult for them to achieve. Five-year-olds should not be expected to learn geometry, for example. What is "proper" for human beings to undertake also seems clear enough: that which is beyond the merely possible in the direction of excellence, but not beyond attainment by the individual. Five-year-olds have the potential to learn table manners and the alphabet and should therefore be encouraged to actualize their moral and intellectual virtues in these ways. Furthermore, although Aristotle states here that age indicates the potential of human beings (Pol 1342b20), his earlier observation that human beings are unequal at birth (tôn gignomenon pantōn) (Pol 1316a13-14) testifies that the human capacity for virtue is not a function of age alone. It may well be proper for some fiveyear-olds to learn geometry.

Requiring individuals to undertake activities that they are able to undertake but that are not easy for them to undertake would seem to be a sufficient, twofold principle for designing educational media. Why then does Aristotle conclude that "the mean" should also be a guiding principle? He in effect accounts for this third term by providing, between his first and second lists of guiding principles, two examples of what education should require which illustrate aiming for the mean in education; taken together they serve to illuminate the meaning of "the possible" and "the proper." The first example proposes that the elderly not be required to sing highpitched harmonies because of the difficulty of their doing so. And since the young will become older, they too should practice the moderate activities that become those who are older (Pol 1342b2029). We are thus cautioned against overreaching in matters of education; there is a difference between virtue and ambition ( $N E$ 1125b18-25) (a teaching that did not guide J. S. Mill's education). The second example submits that children's music both entertain and discipline them ( $\mathrm{Pol} 1342 \mathrm{~b} 29-33),{ }^{23}$ perhaps inspiring controlled and repetitious movement. Here Aristotle tacks in the opposite direction: education should make demands on, not simply

23 Reading paidia ("play") rather than paideia ("education") and taking kosmon to mean "order"; see Politics, trans. Lord, 271 n. 32 and The Politics of Aristotle, vol. 3, ed. W. L. Newman (New York: Arno Press, 1973), 573, note on 1342b31. 
amuse or occupy, human beings (NE 1177a2-3). Taken together, the examples thus illustrate the double entendre of "the mean": the mean is both not-the-extreme and excellence itself (NE 1107a68 ). What is reasonable includes what is difficult. The last paragraph of the Politics therefore exhibits symmetry and communicates the tension implicit in the activity of reaching for excellence which legislators, other educators, and individuals should keep in view. ${ }^{24}$

\section{The Means of Political Education: HABIT AND REASON}

The two guiding principles of education constitute only part of the knowledge required for establishing a good form of education. Legislators must know also the means the principles should direct. Knowing how to induce people to undertake what is both possible and proper for them presupposes, according to Aristotle, knowing what affects or moves the human soul. A legislator must be, then, not just anyone (tou tuchontos) but a knower (tou eidotos) of the soul (NE 1180b25-27). ${ }^{25}$ Legislators must know that the human soul has a nonrational part that responds to habituation and a rational part that responds to reasoned argument, to "listening" (Pol 1332b1-3, $7-8,10-11)$. To what should the nonrational part be habituated and to what should the rational part listen? Aristotle maintains that, since the appetites and desires are inferior to reason, they should be induced to harmonize with it (Pol 1333a16-24). Habit should engender the moral virtues, since "none of [them] arises in us by nature" (NE 1103a17-26). As for reason, it should be persuaded to

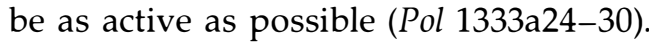

Equipped with the two guiding principles and the knowledge that habituation and argument can improve human beings, legislators developing a system of education should set out to discover (1)

24 The symmetry may be summarized as follows: (1) the possible and the proper stipulated as aims for individuals (lines 17-20); (2) first example: illustration of the possible as the mean qua middle (20-29); (3) second example: illustration of the proper as the mean qua excellence (29-33); (4) the mean, the possible, and the proper stipulated as guiding principles for education (33-34). If the paragraph is an interpolation, as some scholars contend (see Politics, trans. Lord, $271 \mathrm{n}$. 33), it is nonetheless consistent with Aristotle's reasoning.

25 This claim is merely a logical analogue of the claim that, for example, those who care for and train horses should have knowledge of horses (NE 1180b27-28). 
what kinds of habituation effectively improve which age groups (for a good upbringing is not sufficient to render human beings virtuous-even adults need to be induced to practice good habits; NE 1180a1-4); (2) what mixture of habituation and argument is appropriate for the adult population in question; and (3) what the most attractive ways are to induce good habits and to get people to think and study; people are more apt to comply if their doing so yields some sort of pleasure (NE 1172a25-26). If legislators discover these things, then they will have figured out how to encourage moderation (not stoicism), teach trustworthiness (not mere adherence to principles), cultivate judgment (without undermining political friendship), and foster goodwill (without impairing judgment or diluting spiritedness).

\section{Education by Habituation}

In the Politics, Aristotle chooses to discuss the division of the soul in Book VII, which concerns the regime governed by virtuous men. He may thereby be suggesting that even men with the best natures, falling short as they do of being gods, can benefit from habituation; insofar as even they have appetites and desires that occasionally work against the actualization of reason, they can benefit from a disposition that ensures the actualization of reason especially in such circumstances (NE 1180a22-24, Pol 1287a32).

Although one might accept that habitual conduct does not necessarily signify the relinquishment of reason, ${ }^{26}$ one might nonetheless wonder why, apart from the sake of political order or from the point of view of intellectual virtue, reason requires actualization, whether habitual or otherwise. Aristotle's abbreviated answer is that there is a sense in which action completes reason: one cannot be said to know, say, the truth of a precept unless one abides it in practice (NE 1179b2-4). ${ }^{27}$ Aristotle would, then, agree with the Athenian Stranger that "what really makes a difference in education-not only of the young but of ourselves-is not so much the precepts one gives to others, as the way one exemplifies the pre-

26 Of course, it may sometimes signify this, since following a habit or disposition is not always the best thing to do.

27 For Aristotle's unabbreviated answer, see Chapter 8, "The Relation between Moral and Intellectual Virtue," pp. 198-202. 
cepts one would give to another, in one's conduct throughout life." 28 In fact, Aristotle says that what distinguishes a good from a bad political system is whether it forms good habits in its citizens (NE 1103b3-6).

A good disposition may save the virtuous from infrequent lapses of reasonableness, but most human beings must normally rely on their dispositions (NE 1179b4-16). Arguments about human goodness seem to affect those who are young and good-natured and even to inspire those among them who have an inborn yearning for what is noble, but they do not affect most people. Reason or speech alone-lectures, discussion, or writings-cannot impel most people toward nobility and goodness, because they have never experienced the true pleasure that accompanies virtuous activities. Having no conception (ennoian) of virtue or thinking wrongly that they do know what others mean by virtue (and having a wrong conception, understandably finding it repellent), they have no sense of honor and therefore no sense of shame. Consequently, they live by pursuing pleasures and avoiding pain without consideration of whether the pleasures in which they indulge are true ones. ${ }^{29}$ If base activities give them pleasure, then they refrain from them only if they are afraid of suffering the (legal) penalties attached to them. In short, the many, especially but not only when young, find it difficult because they find it unpleasant to live with even moderation and perseverance (NE 1179b31-1180a5). Inclined neither to ascertain what limits they ought to impose on themselves nor to impose voluntarily any such limits on themselves, they need lawmakers and laws to do both of these things for them. The many need laws and an education enforced by law not so much to become noble or excellent but to become self-restrained and thus orderly.

Aristotle seems nonetheless to agree with Plato that some among any multitude would become, as a result of proper habituation, receptive to argument and excellent: "Legislators should exhort people to virtue and urge them forward for the sake of what is

28 Plato, Laws, 729c.

29 Thus, the function of the sense of shame is to promote goodness or excellence in an individual. Similarly, according to Freud, the sense of guilt enables a person to live with others insofar as it checks aggressive impulses. Aristotle and Freud thus agree that shame or conscience is civilization's handmaiden; see Freud, Civilization and Its Discontents (New York: W. W. Norton, 1961), 78-94. 
noble, on the assumption that those who have been promoted in goodness by the formation of habits will respond" (NE 1180a5-8). Because there may be a variety of natures even among the many, all regimes should contain a form of education that prepares them for and invites the pursuit of excellence.

\section{Habituating Children: Physical and Moral Supervision}

The formation of habits preparing individuals for further education should begin before they are required to obey the laws directly, when they are children. Since children's reasoning powers are latent (Pol 1260a12-14), their upbringing should focus on developing their bodies through gymnastic and sports (Pol 1334b25-26, 1338b4-8). The body should be developed, not for the sake of the body itself (health), for the sake of competition (honor), or for the sake of the defense of the city (courage), but for the sake of the whole soul (1334b27-28, 1338b9-16). Light (noncompulsory) exercise serves the soul by making the body more resistant to fatigue and illness that could later distract the soul from its proper work (1338a19-20, b40-42, 1335b8-11).

Since the appetites and desires can, as much as fatigue and illness, interfere with thinking, they too should be disciplined. Teaching children what they should find repellent and what they should love (Pol 1340a15) is in fact a way to promote the later development of their minds, since they will come to love all things noble. ${ }^{30}$ Before puberty, this habituation should take the form of monitoring what children hear and see, so that they do not acquire an element of rudeness or meanness (1336b2-3). Parents or others overseeing children at home should assume this responsibility until children are seven years old; once the regime begins to supervise children, this responsibility becomes also that of legislators and public supervisors of children. Adults should prohibit children from, for example, using or hearing foul words, looking at unseemly pictures, hearing lampoons (iamboi), seeing comedies, or spending time with the household slaves (1336a39-b23). ${ }^{31}$ The young should not be exposed to base things in general, and they

30 See also Plato, Laws, 653b.

31 Lampoons are indecent and abusive verses recited at festivals of Dionysus; see Politics, trans. Lord, 269 n. 81, which refers the reader to Aristotle's Poetics 1448b2449 a15. 
should be kept away especially from anyone or anything that is depraved or hostile (1336b33-35).

According to Plato and Aristotle, it is futile to try to regulate children's conduct by reasoning with them. When a child becomes capable of reasoning he will understand that he was forbidden certain things because children are especially impressionable ( $\mathrm{Pol}$ 1336b33). ${ }^{32}$ Moreover, his "passions can in consonance with reason affirm that they have been correctly habituated in the appropriate habits" and, as the Athenian Stranger explains, "this consonance in its entirety is virtue." 33

\section{Habituating the Young and Adults: Music Education}

When children near puberty, after they have learned the useful skills of writing and drawing (Pol 1337b23-26), their moral education should assume the form of music (mousike)), "the assumption being that, just as gymnastic makes the body of a certain quality, so also is music capable of making the character of a certain quality by habituating it to be capable of taking pleasure in the right sort of way" (1339a21-25, 29-31, 4-5). Having the young actually participate in music-play instruments and sing-is the most effective way to habituate their souls to the moral virtues music represents. ${ }^{34}$ Yet also adults should listen to music for the sake of their characters (1340b20-39). Indeed, Aristotle implies that music can promote the five elements of civic virtue-moderation, trustworthiness, thoughtfulness or judgment, spiritedness, and goodwill. This can be seen in both his confirmation that music is morally educative and his definition of "music."

In addition to the possibility that "music contributes something to virtue," Aristotle raises the alternatives that music, like sleep, drinking, and dancing, is "for the sake of play and rest," and that it "contributes in some way to pastime and prudence" (Pol 1339a14$21,25-26, b 13-14)$. In that "music is one of the greatest of pleasures," it qualifies as a form of play, relaxation, and pastime (1339b14-20). Yet, that "in some way it contributes to the character and the soul" is also evident, for "we become of a certain quality," "we are altered in soul," when we hear music. This is so because

32 Plato, Republic, 378d.

33 Plato, Lawe, 653b.

34 Carnes Lord, Education and Culture in the Political Thought of Aristotle (Ithaca: Cornell University Press, 1982), 97-98. 
rhythms and tunes imitate or are like qualities pertaining to character. They may evoke anger, serenity, valor, frenzy, passion, or composure, for example. Music has the power to make us feel similar to what we hear. In fact, although we hear only "imitations of characters," these can produce in us a condition close to the true character-sad songs tend to make us sad. Therefore, to ennoble our characters, we should play, sing, or listen to music that inspires nobility (1340a6-12, 18-25, 38-39, 1342b1-3, 12-17).

Music is an ideal medium for producing good character because it can also arouse pleasant feelings; ${ }^{35}$ having a good character means in part liking, desiring, or having pleasant feelings toward good things (Pol 1340a14-18). Thus, enjoying good, beautiful, or noble music over time habituates a person to experience pleasure in good, beautiful, or noble things in general. When not partaking in music, such a person seeks out good things (or judges correctly), for these have become enjoyable. ${ }^{36}$

From Aristotle's claim that certain sorts of music can create or inspire in a performer or listener corresponding sorts of character, one might infer that music can therefore inspire the civic virtues. Indeed, to repeat, he says that music can inspire moderation or steadfastness and courage or spiritedness (Pol 1342b12-17). That it can elicit sociality or goodwill is obvious and a main reason why human beings accompany their social gatherings and pastimes with singing or performed music, especially cheerful music (1339b21-24).

But can music inspire trustworthiness and thoughtfulness or judgment? In fact, Aristotle indicates that judging or critically evaluating music improves moral judgment (Pol 1340a14-18). But this seems most implausible; developing technical or aesthetic judg-

35 Things we taste and touch can produce pleasure but do not seem to affect character; what we see, like what we hear, affects the soul and can produce pleasure, but Aristotle claims that pictures and statues cannot affect character as much as music because they are "not likenesses" but "indications of characters" (Pol 1340a28-35; Politics, vol. 1, ed. Newman, 363). Aristotle might have judged differently had he lived in the age of photography.

36 See also Plato, Republic, 401d-e. On Aristotle's point, see also Politics, trans. Barker, 343 n. 3; Politics, vol. 1, ed. Newman, 363, 368, 372; Lord, Education and Culture, 93. Newman explains that, "in order fully to understand the importance of the part assigned by Aristotle to music in the development of the spoudaios, we must bear in mind that to him, unlike some modern moralists, a man is not really virtuous unless he finds pleasure in the exercise of virtue. It is precisely this identification of the good and the pleasurable that music is the earliest means of producing" (368). 
ment, such as the Spartans claim to have done (1339a42-b4), does not seem to improve one's moral character necessarily. Aristotle even says that citizens should not partake of music with a view to becoming experts or professionals. ${ }^{37}$ They should not perform in contests or attempt to execute difficult music, for such training impairs bodies for military service and diverts attention later from civic duties and the pursuit of knowledge. What is more, undertaking a musical education for the sake of becoming a professional, of playing for an audience, corrupts its educative purpose, since one plays not for one's own virtue but in the spirit of a laborer trying to please others (1341a5-13, b8-18). At the same time, Aristotle says that citizens should not simply enjoy music, like children, slaves, and even some animals (1341a13-17), thus returning us to the notion that music affects the soul by engaging thought.

How music may affect moral judgment beyond habituating the soul to what is noble-how it may be said to teach or educatebecomes evident once one appreciates that by music Aristotle does not mean merely audible harmony but also poetry. He says, for example, that music is pleasant "both by itself and with melody" (Pol 1339b20-21) and speaks of "tunes by themselves" or "harmonies" and "rhythms" (1340a38-40, 13-14, b17-18, VIII.7). The flute, he argues, should not be taught because it "prevents speech" and educating "the mind [tèn dianoian]" (1341a24-25, b2-8). Most telling, he declares in his discussion of music education that "one should learn and become habituated to nothing so much as to judging in correct fashion of, and enjoying, respectable characters and noble actions" (1340a16-18) — not only tunes but a story may imitate or portray characters. Aristotle must mean that by evaluating the characters and deeds depicted in a poem (or literature), one may learn moral lessons. Thus, he agrees with Odysseus that music is the best pastime (diagōge) (1338a21-22, 28)-literally, the best way "to lead across life." 38

Aristotle may deem music - with or without tunes-the best pastime because it compels reflection about ethics, but he characterizes the experience of listening to it less as an intellectual than as

37 For the claim that Aristotle does not think music should promote technical or aesthetic judgment, see Lord, Education and Culture, 74-75, 99-103.

38 In other words, "diagōge rightly understood . . . is fundamentally 'ethical' or 'educative' activity" (ibid., 103). Credit for observing that Aristotle's concept of mousike includes poetry and that he believes that it can affect the soul is due to Lord (ibid., 65-66, 86-89, 103, 109, 139-41). 
a moral experience. ${ }^{39}$ For example, he says that "all who listen to imitations apart from rhythms and tunes themselves come to experience similar passions" (Pol 1340a12-14). In fact, music can morally improve human beings not only by way of teaching or education (paideia) but also by way of purification or catharsis (katharsis) (1341b36-38). Just as certain sorts of tunes calm the soul by way of making it frenzied (1342a7-11), so certain forms of poetry-especially tragedy and comedy-may temper human beings by making them suffer the painful consequences of excessive passion. ${ }^{40}$ Human beings become more thoughtful less by analyzing than by vicariously experiencing moral dilemmas.

In conjunction with characterizing music education as a fundamentally moral education, Aristotle indicates that music education should also assume the form of theater ( $\mathrm{Pol} 1342 \mathrm{a} 16-18)$. These two points suggest that music education is suitable for any free adult populace. This is not to say that all citizens everywhere would profit morally from attending tragedic or comedic public spectacles; their individual natures, private upbringings, and even the nature of the laws would bear on the educative effect of theater. Nonetheless, public musical spectacles achieve a politically salutary effect even when "vulgar persons and laborers" listen to them, insofar as they keep them occupied and entertained when they are not working (1342a15-22). ${ }^{41}$

In sum, Aristotle brings us to the conclusion that "music" is the best way to promote civic virtue in citizens. The right kind of music can render souls, particularly but not only youthful ones, temperate, spirited, goodwilling, and noble (of good judgment and trustworthy) (Pol 1339b24-25, 1340b10-13, 30-31). Citizens habituated by music throughout life and also by the laws when adults ( $N E$ 1180a1-3) develop virtue that stands as a mean relative to the regime.

39 Ibid., 65-66.

40 Ibid., 173-77 (Lord makes several references to Aristotle's Poetics); see also 3435. Lord's explanation makes clear that the katharsis poetry effects is not simply the release of emotions in a harmless manner, which would only moderate rather than purify or eliminate the passions (see especially $176 \mathrm{n}$. 54). Thus, one can see why Aristotle thinks that poetry is superior to religion as a means to bring about civic virtue.

41 On the theater, see ibid., 202 n. 27. For the claim that Aristotle thinks that music is the best pastime for mature citizens, see $34,73,83-84,93-96,102,112,147$, 152. 


\section{Leisure: Education in ReAson?}

The previous chapter discussed the ways that laws should superintend the bodies and conduct of adults. But habituation alone, even if effected from the beginning until the end of a life, cannot make a human being good. A complete education, one that enables a human being not only to be a good citizen but to rule both self and others-one that completes a human being-must include leisure (schole).

That Aristotle does not define scholē may be due, as J. L. Stocks suggests, to the term's having been in popular use at the time of his writing. Aristotle did not need to explain to his audience that by schole he meant spare time, without pressing duties, spent in voluntarily undertaken schooling or study. ${ }^{42}$ Nor did he need to point out the three main elements of leisure: freedom from labor, autonomy, and education. According to Friedrich Solmsen, Aristotle did not even need to persuade his audience of the value or necessity of leisure, for the Peloponnesian War had some twenty-five years before the founding of Plato's Academy generated in a portion of Athenians "a longing for the quiet of leisure." Plato and Aristotle discovered not the value of leisure but the best content for it. ${ }^{43}$ They took it on themselves, perhaps in response to what they perceived as a need, to articulate the essence and communicate the spirit of leisure, to rank and explain its nature and constitutive elements-which they took to be (1) economic security (freedom from the necessity to labor), (2) psychological freedom (freedom from worries and cares), (3) a condition of quietude or peace ${ }^{44}$ and thus freedom from even political activity, (4) self-direction, or "time for oneself," 45 and (5) education. Declaring that education should be the essence of leisure, Plato and Aristotle sought to explain what sort of education leisure should entail and why.

In the following discussion, I show or suggest the emphasis Aristotle places on each element of leisure. I note where he may

42 J. L. Stocks, "Scholē," Classical Quarterly 30 (1936), 181.

43 "Leisure and Play in Aristotle's Ideal State," Rheinisches Museum für Philologie 107 (1964), especially 201, 204, 206. On who the Athenian quietists were and how they manifested quietism (apragmosunēe), see L. B. Carter, The Quiet Athenian (Oxford: Clarendon Press, 1986).

44 As its etymological root ("to halt or cease") implies; see Sebastian de Grazia, Of Time, Work, and Leisure (New York: Twentieth Century Fund, 1962), 12.

45 Stocks, "Scholēe," 181; Grazia, Of Time, Work, and Leisure, 12. 
have derived his thoughts from Plato's account, but I do not seek to distinguish their contributions systematically. ${ }^{46}$

\section{What Leisure Is Not}

To understand Aristotle's conception of leisure, one should first note that he contrasts leisure to occupation (ascholia): schole and ascholia are as different as peace and war (Pol 1333a30-32, NE 1177b4-6). Ascholia means approximately "busyness," not "labor," for which there is the more specific ponos. Because labor keeps one busy, ascholia technically includes labor, but it generally means any necessary activity one would rather not do. ${ }^{47}$ In the Nicomachean Ethics Aristotle allows that political actions can be noble and great but calls them unleisurely (ascholoi) (1177b6-18). Politics in his view appears to be a combination of the necessary and the noble and no part of leisure.

Because leisure is not for the sake of the necessary (Pol 1333a30$36)$, one cannot be busy meeting one's needs and be at leisure. One must have wealth enough to have not only free time, but the amount of time that holding political office demands; "a moderate amount of property" is insufficient ( $\mathrm{Pol}$ 1273a24-25, 1291b25-26, 1292b25-29). ${ }^{48}$ But Aristotle indicates that one does not need great wealth to have the time to rule when he proposes that government support the respectable who are poor when they are ruling (1273a32-b7). Indeed, if leisure is not busyness, then it must require not having wealth in an amount that demands constant upkeep, guarding, or managing. Being at leisure requires having that amount of wealth that fosters indifference toward it. ${ }^{49}$

In opposing leisure to occupation, Aristotle at once excludes play (paidia) and relaxation or rest (anapausis) from his conception of leisure. Human beings play or amuse themselves in order to relax

46 Solmsen proposes that Aristotle's contribution is to advocate incorporating schole into the city as an education for all citizens, against Plato's intention to confine schole to the philosopher's school ("Leisure and Play," especially 206-7).

47 See Grazia, Of Time, Work, and Leisure, 14-15.

48 For discussion on the point that it is hardly fair to attribute to class prejudice Aristotle's contention that wealth is a requirement of leisure, see Solmsen, "Leisure and Play," 218.

49 Thus, Grazia captures not the letter but the spirit of the philosophers' ideal of leisure when he explains that "commodities are irrelevant. A walk outdoors will do. As the Republic opens, Socrates goes to the house of a rich old man named Cephalus. It took no show of commodities to get him to make the visit. To lure Socrates all you needed was the promise of conversation. How Cephalus's house looked or was furnished had little importance" (Of Time, Work, and Leisure, 348). 
or rest, but they need to relax or rest only after they have been busy or exerted themselves (Pol 1337b38-39). Play or recreation is not, in other words, for its own sake, but for the sake of relieving one from occupation. It is necessary because one cannot work constantly (NE 1176b34-35). Play should thus be regarded as simply a remedy to occupation (Pol 1337b41-42) - its complement (not its opposite) and never an end in itself. "Indeed, it would be absurd if the end [of life] were amusement, and one were to exert oneself and suffer throughout life in order to amuse oneself" (NE 1176b28-30).

Similarly, leisure is not spare time to do as one pleases or to be idle or licentious. Aristotle makes this point at least four times in the Politics. In Book I he remarks that nomadic shepherds "derive sustenance from domesticated animals without toil [ponos]" "and so have leisure [scholazousin]," yet he calls their way of life "the idlest [argotatoi]" (1256a31-32). He is not praising them for having found a way to live that frees them from labor but criticizing them for failing to live in a truly leisurely fashion. In Book II he remarks that, although the serfs in Thessaly and the Spartan helots apparently had time to prepare an attack on their masters, they cannot be said to have had leisure for they lived constantly awaiting the opportunity for ambush (1269a38-39). Thus, time spent merely waiting is not leisure. In the same chapter, Aristotle relates the unfortunate situation that arose in Sparta. The Spartan men, having become self-controlled and accustomed to observing rules as a consequence of their military training and actual combat, were evidently well-prepared to receive further instruction in virtue during peacetime (1270a1-6, 1334a24-25, 1269b19-21). ${ }^{50}$ In contrast, the Spartan women, having no experience of military life, lived "licentiously in every respect and in luxury," refusing to abide by the laws, both when the men were away at war and after they returned, during peace $(1269 \mathrm{~b} 22-23,1270 \mathrm{a} 1-2,6-9)$. Aristotle makes clear that he is not raising this example to denounce women in general or even the Spartan women. The issue is not the propensity of one sex or the other for licentiousness. Nor is his aim to blame any particular party for the situation that arose (1270a9-11), though by explaining what led to the women's way of life he is in effect excusing them. Rather, he is saying, first, that human beings

50 Yet Aristotle later denounces the Spartan men for "not knowing how to be at leisure" (Pol 1271b2-6). He thereby indicates here, in Book II, that military experience is not the right sort of preparation for leisure and thus makes us anticipate his discussion of laws and music as proper modes of habituation. 
must learn how to use free time. The Spartan regime should have educated its women about spending time in the way that becomes human beings. Second, this example indicates that people should know how to be at leisure during both war and peace. Aristotle implies that, had the women known how to be at leisure when Sparta was at war, they would have been able to rule themselves; had they known how to be at leisure during peace, they would have known how to be ruled. Leisure, it appears, teaches how to rule and be ruled; it appears to promote political virtue. Finally, Aristotle distinguishes leisure from spare time to do as one pleases in Book VIII, where he observes that "being at leisure . . . seems to bring in itself pleasure, happiness, and living blessedly" (1338a13 ), for "the happy life seems to be a life expressing virtue, which is a life involving serious actions, and not consisting in amusement" (NE 1177a1-3). If being at leisure brings happiness, then it cannot also mean simply living as one likes. In summary, as Sebastian de Grazia notes, "[although] in some cases it seems that leisure is another word for spare or free time, ... one senses a different element, an ethical note, a hint that spare time when misused is not leisure." 51

But what exactly is this ethical element? By opposing leisure to occupation, Aristotle may be suggesting that leisure's ethical component is the opposite of occupation's ethical component. Leisure's ethical component, whatever else it may or may not be, is not necessary tasks accomplished or products produced. In light of Aristotle's claims that "life is action not production" and "man is by nature a political animal" ( $\mathrm{Pol}$ 1254a7, 1253a2-3), one might speculate that leisure is ethical because it is purely social or exemplary of species life. Perhaps Aristotle is implying what Marx stated explicitly-that the life "opposed to [man's] material life" is "the species life [Gattungsleben]," which is man's perfected political condition. According to Marx, to be human and free requires being conscious that one is a member of a species and living in accordance with that consciousness. Perhaps Aristotle is suggesting that leisure instills this consciousness and way of life. ${ }^{52}$

51 Of Time, Work, and Leisure, 13.

52 Karl Marx, "On the Jewish Question," in The Marx-Engels Reader, ed. Robert C. Tucker (New York: W. W. Norton, 1972), 31-32. In his brief discussion of Marx's concept of leisure, Grazia notes that "Marx seems to have been groping for a fresh expression of the classical concept" (Of Time, Work, and Leisure, 350-51). 
On this account, leisure's value lies in its capacity to render individuals fit for community life. Not necessary to individual survival, it appears nonetheless necessary to collective survival. But Aristotle places leisure among the noble, not the necessary or useful ( $\mathrm{Pol}$ 1333a30-b3); leisure is not for the sake of something else, even the body politic. What is more, the happiness human beings find in leisure varies according to their individual natures and characters (Pol 1338a1-8). By contrast, leisure understood as the fulfillment of oneself through species life presupposes that happiness is the same for all.

\section{What Leisure Is}

According to Aristotle, one cannot live pleasurably, happily, and blessedly or be at leisure without complete virtue (Pol 1338a1-3, $N E$ 1100a4-5), which requires habituation and education-since habituation engenders the virtues of character (ethikess), and teaching, the virtues of thought (dianoètikés) (NE 1103a14-17, 31) (though nature contributes the potentiality to both sorts of virtue; NE 1103a23-25, 1179b21-23; Pol 1331b24, 29-41).

By saying that music is the best pastime in leisure, Aristotle implies that there are other such pastimes (diagoggai). "Subjects of education," "sorts of learning . . . for their own sake," should be studied in leisure (Pol 1338a9-12). Carnes Lord points out a forward reference ( $\mathrm{Pol}$ 1338a30-37) and Book VII's introduction to education as evidence that the missing chapters of Book VIII discussed the liberal arts other than music. ${ }^{53}$ Aristotle also associates leisure with the development of sciences unrelated to utility, of which he gives the mathematical sciences as an example (Met 981b21-26). Taken together, this evidence all but confirms that Aristotle means by "leisure" the liberal arts, or "culture." 54

That he intends philosophy or contemplation to be counted among the liberal arts is clear, since he says that leisure provides the full range of happiness (Pol 1338a1-9). ${ }^{55}$ But perhaps it would

53 Education and Culture, 150.

54 See also Leo Strauss, The City and Man (Chicago: University of Chicago Press, 1964), 31; Lord, Education and Culture, especially 19, 23-24, 29, 180, 198-202.

55 Lord maintains that Aristotle uses "philosophy" both in the precise sense, meaning "theoretical speculation," and "in a looser sense of what would today be called 'culture'"; this implies that Aristotle sometimes uses "philosophy" to mean leisure and thus sometimes subsumes theoretical speculation under philosophy (Education and Culture, 199-200, 202). This interpretation solves more difficulties 
be more precise to say that the liberal arts should prepare those who are capable for contemplation, in particular by instilling in them a love for learning or thoughtful activity for its own sake; for Aristotle does not expect that even all the best persons have the capacity for contemplation (Pol 1331b39-41, 1333a25-30). ${ }^{56}$

What good men can develop is good judgment and eventually prudence (Pol 1277b25-29; NE 1142a14-16, 1143a29-31). Since each man judges well what he knows, Aristotle reasons, the best way for him to become "a good judge in general" is for him to receive "an all-round education" (NE 1094b28-1095a2). Such an education is both possible and proper for those human beings with an adequate nature and habituation (Pol 1332a38-40, 1291b25-30). Each would benefit from leisure in accordance with his own disposition (Pol 1338a7-9). ${ }^{57}$ If citizens follow a course of liberal education enforced by law when young, and as a result of that education voluntarily avail themselves of culture when adults, then a city becomes unified in the way and to the extent that Aristotle thinks a city should (Pol 1337a21-27, 1263b31-37).

\section{Leisure: Private and Public Good}

Benefiting the individual through education, leisure appears to be a private good. Indeed, as Solmsen maintains, Aristotle leaves the impression that leisure should promote primarily not civicmindedness or the virtues of citizenship but private happiness. ${ }^{58}$ By encouraging citizens to become good judges in general, leisure encourages them to reflect not only on the best way of life relative to their regime but on the best way of life simply. A complete liberal education asks students to become not good citizens but good human beings.

than it creates, but one should not lose sight of the fact that Aristotle sometimes means by "philosophy" contemplation or theoretical speculation of the highest sort; for example, reading "philosophy" as "culture" does not, as Lord argues, make sense of Aristotle's claim that "philosophy [is required] with a view to leisure [philosophias de pros tèn scholèn]" (Pol 1334a23) if leisure is itself defined as culture. I explain the respect in which contemplation is required with a view to leisure at the end of this chapter.

56 See also Solmsen, "Leisure and Play," 218; Lord, Education and Culture, 64, 199.

57 See also Grazia, Of Time, Work, and Leisure, 348-49.

58 According to Solmsen, Aristotle thus reveals sympathy for Hellenistic over classical tendencies ("Leisure and Play," 219-20). 
But by becoming through leisure good human beings, individuals in fact become exemplary citizens in that they develop, insofar as they have deliberated about what is good for human beings, prudence (NE 1141a23-28, b8-9), the virtue enabling one to rule (Pol 1277a14-16, 29-31). ${ }^{59}$ By providing leisure, then, a regime furnishes itself with potential rulers, increasing its chances for just rule. Evidently, "there is a need for leisure both with a view to the creation of virtue and with a view to political activities" (Pol 1329a1-2). ${ }^{60}$ Aristotle seems to agree with the Athenian Stranger that a true education is one "that makes one desire and love to become a perfect citizen who knows how to rule and be ruled with justice," and that all other sorts-such as education "that aims at money, or some sort of strength, or some other sort of wisdom without intelligence and justice" —are "vulgar, illiberal, and wholly unworthy to be called education." 61 In sum, because leisure serves the public through the private, Aristotle suggests that all regimes incorporate it ( $\mathrm{Pol} 1273 \mathrm{a} 32-35,1333 \mathrm{a} 30-\mathrm{b} 3) .{ }^{62}$

Since leisure aims to cultivate both political and complete virtue, it aims to develop in particular the capacities that most characterize those forms of virtue. It has become evident that prudence (phro$n \bar{e} s i s$ ) is the leading capacity of political virtue, since it most enables one to rule; and Aristotle says in Book VI of the Nicomachean Ethics that wisdom (sophia) leads among the intellectual virtues (1141a1617) and thus completes virtue. A brief discussion of prudence and wisdom should, then, illuminate the objectives of leisure.

Prudence and wisdom differ radically in that "the content of wisdom is always the same, but the content of prudence is not"

59 See also Lord, Education and Culture, 177-79.

60 This statement works against P. A. Vander Waerdt's thesis that citizens in the best regime would not rule (see Chapter 5, "Political Laws: Offices and Entitlement," pp. 124-26).

61 Plato, Laws, 643e, 644a.

62 Grazia points out that the classical ideal of leisure "has been deformed almost everywhere" because leisure and democracy are not compatible: "The point at which the deformation is most obvious is in the idea that leisure is owed everyone and everyone can benefit from it in equal measure. The educators try to say that leisure and democracy were destined for each other. To the Greeks, who were more liberal than we in the matter of bedfellows, these two would still be strange partners" (Of Time, Work, and Leisure, 348-50). Aristotle advocates introducing leisure into inferior regimes, not because he thinks that everyone has a right to it and can benefit from it equally, but because he thinks that everyone has a duty to better themselves and that it is in the interest of government to provide the means for them to do so, since a liberally educated citizenry is perhaps the best means by which inferior regimes can be incrementally transformed into better ones-polities or aristocracies. 
(NE 1141a24-25, Met 1074b26-27). The content of wisdom never changes, because it comprehends what is highest by nature (NE 1141a22-23, 34-b3). The content of prudence changes because it addresses human concerns. Prudence is the faculty with which human beings deliberate about what is good for themselves ( $N E$ 1141a23-28, b8-9). It is also the faculty that effects what is good for human beings (1141b12-14, 1140b1-4) and therefore lends itself to both political science and politics (1141b24-1142a10). Prudence is closer to the virtues of character than it is to wisdom, is more like a moral than an intellectual virtue, for three reasons. First, the prudent, in order to put into practice what is good for human beings, must engage the moral virtues (NE 1178a16-19). Second, the work of prudence requires human beings as objects or recipients of action and human things such as money, power, and freedom (1177a30-32, 1178a24-b3). To perform its work it needs, so to speak, to be complemented both internally and externally. Third, prudence is like a moral virtue in that it serves wisdom ( $N E$ 1145a6-11); it does not have command over the intellect.

In contrast, because the faculty of wisdom (nous) aims to grasp the truth about the first principles, to understand what accounts for scientific knowledge (NE 1141a3-8, 17-20, b2-3), its activity is self-sufficient; the wise person is the most self-sufficient of human beings, being able to contemplate (theörein) alone (NE 1177a32-b1). For such a person external goods "are even hindrances" (1178b3-5, 1179a1-5). ${ }^{63}$ Nonetheless, the experience of constancy is a happy one: "We think happiness has pleasure mixed into it; and the activity in accordance with wisdom is admittedly the pleasantest of the activities in accordance with virtue; at any rate, philosophy seems to have pleasures marvellous for their purity and enduringness, and it is to be expected that those who know will pass their time more pleasantly than those who search" (1177a22-27).

The best human life, then, paradoxically requires turning away from merely mortal thoughts and striving as much as possible to live in accordance with the most excellent, powerful, and valuable thing in a human being; one should try to become, in a word, immortal (athanatizein) (NE 1177b31-1178a2). Exercising one's di-

63 Aristotle acknowledges that the person who contemplates of course needs the sorts of external goods necessary for living as a human being, interacting virtuously with others (NE 1178a24-25, b5-7). For further discussion of contemplation, see Chapter 8, especially "Intellectual Virtue and Contemplation," pp. 193-98. 
vine element to approach immortality requires not acting or speaking much at all. Speeches and deeds cannot confer immortality because they must, like all particulars, pass away.

Why, then, from the city's point of view, should leisure encourage contemplation? It has been argued that according to Aristotle becoming a good or prudent human being requires simply considering through leisure the virtues of the supreme way of life, not necessarily leading that way of life. By evaluating the contemplative life (perhaps Socrates'), citizens would come to realize that those who engage in "those speculations [theörias] and thoughts [dianoēseis] that are for their own sake" are also acting well and moreover in the most self-sufficient way available to human beings (Pol 1325b12-21, 29-30, 1325a32). On this reading, a liberal education should work to preempt the forming of or eradicate the common prejudice that philosophers are inactive parasites. Citizens examining the contemplative life would also conclude that a regime must allow citizens to choose that way of life if the regime's intent is, as Aristotle says it should be, to allow and facilitate the happiness of which each is capable. In sum, by appreciating the complete coincidence between virtue and freedom and thus that philosophers set the standard for choice, citizens would become gentlemen.

Aristotle hints nonetheless that philosophy can make a direct, substantive contribution to the city when he states that "philosophy [is required] with a view to leisure" (Pol 1334a23). Apparently, philosophical insights are required to establish the best form of education, one that produces good rulers and good human beings. Perhaps the single most important insight needed for the task is that human beings are part divine, part not-divine (NE 1177b2628, 1178a6-7; Pol 1333a16-18). ${ }^{64}$ Only philosophers can know the full meaning of this universal truth because they are able to experience the divine (NE 1177b26-31, 1178a22); only this perspective illuminates the limitations and the potentialities of a bifurcated existence. By understanding the divine, a philosopher under-

${ }^{64}$ Nature repeats in humanity the "irreducible duality" that characterizes "the whole of nature" for the sake of the principle of the whole: if human beings did not make "due allowance" to "the grossly necessary" and "surrender to the incorruptible nature" - if they did not try to resist gross nature to the extent permitted by the incorruptible - political life would be incompatible with the whole of nature; Joseph Cropsey, "Political Life and a Natural Order," in Political Philosophy and the Issues of Politics (Chicago: University of Chicago Press, 1977), 227. 
stands the whole of nature (Met 1074b3) and therewith the relation between human beings and the natural order. He sees the truths that characterize this relation, such as that "all partnerships aim at some good" (Pol 1252a4); "nature makes nothing in an economizing spirit" (1252b1-3); "everything is defined by its work and its capacity" (1253a23); things diverge toward either ruling or being ruled (1254a21-36); nature intends but does not achieve a correspondence between the quality of bodies and that of souls (1254b27-33); and nature makes mere life sweet (Pol 1278b25-30). A philosopher understands the reasons for these truths insofar as he sees the unity of the whole of nature.

In understanding the natural truths, a philosopher sees how human beings should be educated so that they may harmonize with the natural order. And, although he is not inclined to establish the requirements of education through legislation-that is, to partake in the legislative process-he may transmit his knowledge of the natural truths through private teaching and writing, as did Socrates, Plato, and Aristotle himself, thus influencing the ways of life of those who listen and comprehend, and thus influencing future legislation. 